КЛИНИЧНИ СЛУЧАИ

CASE REPORTS

\title{
ДЪЛГОСРОЧЕН ЕФЕКТ НА ХУМАНИЗИРАНО МОНОКЛОНАЛНО АНТИТЯЛО СРЕЩУ РЕЦЕПТОРА ЗА ИНТЕРЛЕВКИН-6 ПРИ ПАЦИЕНТ С АРТЕРИИТ НА ТАКАЯСУ
}

\author{
Т. Сапунджиева ${ }^{1,2}$, Р. Каралилова ${ }^{1,2}$, А. Маринков ${ }^{1,2}$, А. Баталов ${ }^{1,2}$ \\ ${ }^{1}$ Катедра по пропедевтика на вътрешните болести, Медицински фракултет, Медицински университет - Пловдив \\ 2Клиника по ревматология, УМБАЛ „Каспела“ - Пловдив

\section{A LONG-TERM EFFECT OF A HUMANIZED ANTI-INTERLEUKIN-6 RECEPTOR ANTIBODY IN A PATIENT WITH TAKAYASU ARTERITIS}

\author{
T. Sapundzhieva ${ }^{1,2}$, R. Karalilova ${ }^{1,2}$, A. Marinkov ${ }^{1,2}$, A. Batalov ${ }^{1,2}$ \\ ${ }^{1}$ Department of Propedeutic of Internal Diseases, Medical Faculty, Medical University - Plovdiv \\ ${ }^{2}$ Rheumatology Clinic, University Hospital „Kaspela“ - Plovdiv
}

\begin{abstract}
Резюме. Артериитът на Такаясу (ТАК) се отнася към групата на васкулитите на големите съдове, като засяга аортата и основните ѝ клонове. Съществуват доказателства, че повишената продукция на интерлевкин-6 (IL-6) има ключова роля в патогенезата на TAK. Представяме клиничен случай на жена с рефрактерен ТАК, при която започнахме терапия с тоцилизумаб - моноклонално антитяло срещу рецептора за IL-6. В резултат на лечението настъпи подобрение на клиничните симптоми и на лабораторните показатели, което даде възможност да се редуцира дозата ГКС без последващ релапс на болестната активност за периода на проследяване от 2 години. Тези резултати показват, че инхибирането на IL-6 пътя може да бъде част от терапевтичната стратегия при пациентите с рефррактерен ТАК.
\end{abstract}

Ключови думи: артериит на Такаясу, биологично лечение, интерлевкин 6 (IL-6), тоцилизумаб

Abstract. Takayasu arteritis (TAK) is a large-sized vessel vasculitis that involves the aorta and its major branches. The overproduction of interleukin-6 (IL-6) has been proved to play a major role in the pathogenesis of TAK. The following case report describes a 21-year-old woman with refractory TAK, treated with tocilizumab - IL-6 receptor antibody. As a result of the treatment, the clinical manifestations and the abnormal laboratory findings were improved, which allowed the tapering of the glucocorticoids without a consequent relapse of the disease for a follow-up period of 2 years. The results suggest that inhibition of the IL-6 pathway may be a possible treatment option for patients with refractory TAK.

Key words: Takayasu arteritis, biologic treatment, interleukin-6 (IL-6), tocilizumab

\section{ВъведЕНИЕ}

Артериитът на Такаясу (ТАК) се отнася към групата на васкулитите, засягащи големите съдове (large-sized vessel vasculitis - LVV), и се характеризира с възпаление на аортата и нейните главни клонове. ТАК е рядко заболяване в Европа и Северна Америка. Болестността е по-висока в Азия и Средния изток с честота в Япония приблизително

\section{INTRODUCTION}

Takayasu arteritis (TAK) is a large-sized vessel vasculitis (LVV) characterised by inflammation of the aorta and its major branches. TAK is a rare disease in Europe and North America. Prevalence is higher in Asia and the Middle East, with approximately 60 cases per million, reported in Japan [24]. It is more common in young women, approx- 
60 случая на милион население [24]. Заболяването е по-често сред младите жени на възраст около 20 години [10]. Симптомите са разнообразни и зависят от вида на засегнатия съд, степента на болестна прогресия, като включват едновременно системни симптоми, резултат от органна исхемия (клаудикацио на горния крайник и на челюстта, главоболие, синкоп, артериална хипертония и т.н.) [24]. Персистирането на възпалението при пациентите с ТАК може да доведе до тежко увреждане на съдовете и впоследствие - до органна недостатъчност [5, 11]. Има доказателства за наличие на повишен брой Th1 и Th17 клетки и за повишена концентрация на различни цитокини, включително на тумор-некротизиращия фактор- $\alpha$ (TNF- $\alpha$ ), интерлевкин 6 (IL-6), IL-17A, IL-8, IL-18 и ү-интерферон [3, $12,18]$, при пациентите с ТАК. Доказано е още, че повишените нива на IL-6 се асоциират с по-висока болестна активност [18].

Конвенционалната ангиография дълго време беше образният метод, приеман за „златен стандарт" при поставяне на диагноза и мониториране на пациентите с ТАК, но понастоящем не се препоръчва поради рисковете, свързани с процедурата [7]. Според новите препоръки на Европейската съсловна организация на ревматолозите (European League Against Rheumatism - EULAR) за приложението на образните методики при пациентите c LVV ядрено-магнитният резонанс (ЯМР) трябва да е изследване на първи избор за поставяне на диагноза ТАК [7]. Като алтернативни методи при поставяне на диагноза и мониториране на лечението при пациентите с ТАК могат да се използват [18F] флуородеоксиглюкоза позитрон-емисионната томография (fluorodeoxyglucose positron emission tomography - [18F]FDG-PET), компютърната томография (КАТ) и ултрасонографията с цветен доплер (Colour Doppler Ultrasonography - CDUS) [7, 15].

Според новите препоръки на EULAR от 2020 г. за лечение на пациентите c LVV глюкокортикостероидите (ГКС) са първа линия лекарствени средства за лечение на болните с ТАК, като за индукция на ремисия при активен ТАК е необходимо незабавно прилагане на висока доза ГКС (40-60 мг/дневно преднизонов еквивалент) [9]. ГКС имат дългосрочни странични ефекти и при намаляване на дозата често се наблюдават релапси на болестната активност [13]. Според новите препоръки на EULAR от 2020 г. всички пациенти с ТАК трябва да бъдат лекувани с небиологични болестопроменящи противоревматични средства (disease-modifying anti-rheumatic imately 20 years of age [10]. Disease symptoms vary depending on vascular involvement and the degree of disease progression and include systemic symptoms, together with symptoms from organ ischaemia (upper limb and jaw claudication, headache, syncope, arterial hypertension, etc.) [24]. Persistent inflammation in patients with TAK can lead to severe vascular damage, thus leading to organ failure $[5,11]$. There is an increase in the number of Th1 and Th17 cells in patients with TAK, as well as in the concentration of different cytokines, including tumor necrosis factor- $\alpha$ (TNF- $\alpha$ ), interleukin-6 (IL-6), IL-17A, IL-8, IL-18 and interferon- $\gamma[3,12,18]$. Evidence exists that elevated IL-6 levels are associated with increased disease activity [18].

X-ray angiography was the "gold standard“ imaging method for the diagnosis and monitoring of patients with TAK, but it is no longer recommended due to the risks associated with the procedure [7] According to the new 2018 EULAR recommendations for the use of imaging in LVV, magnetic resonance imaging (MRI) should be used as the first imaging test to make a diagnosis of TAK [7]. As an alternative imaging method, [18F] fluorodeoxyglucose positron emission tomography ([18F] FDG-PET), computed tomography (CT), and Colour Doppler Ultrasonography (CDUS) may be used for the diagnosis and follow-up of patients with TAK $[7,15]$.

According to the new 2020 EULAR recommendations for the management of LVV, glucocorticoids (GCs) are first-line treatment for patients with TAK and high dose glucocorticoid (GC) therapy (40-60 $\mathrm{mg} /$ day prednisone-equivalent) should be initiated immediately for induction of remission in active TAK [9]. GCs have long-term adverse effects, and disease relapse is frequent during GC tapering [13] Non-biologic disease-modifying agents should be given in combination with GC in all patients with TAK according to the 2020 EULAR recommendations, although they have not shown major clinical benefits or any steroid-sparing effects [9, 13]. Unlike giant cell arteritis, where tocilizumab is preferred over methotrexate in refractory or relapsing disease, or the presence/ increased risk of GC related adverse effects, in TAK, Tocilizumab or 
drugs - DMARDs) в комбинация с ГКС, въпреки че според литературните данни първите не са демонстрирали значими клинични ефекти или стероид-спестяващ ефект [9, 13]. За разлика от гигантоклетъчния артериит, където при рефрактерно/с чести релапси заболяване и/или при повишен риск от странични ефекти от ГКС, на първо място, се препоръчва тоцилизумаб, а като алтернатива метотрексат, при ТАК тоцилизумаб/TNF инхибитори се препоръчват на второ място, след неуспех от проведената конвенционална терапия с DMARDs [9]. Лечението с TNF блокери е с доказани клинични ефекти и стероид-спестяващ ефект при пациентите с ТАК, неотговарящи на лечение с конвенционалните имуносупресори, но до момента няма рандомизирани клинични проучвания [6, 13, 14, 20]. Съществуват редица данни за ефекта на моноклоналното антитяло срещу рецептора за IL-6 при пациентите, рефрактерни на терапия с TNF блокери $[2,8,16$, $19,22,23]$. До момента има само едно рандомизирано, плацебо-контролирано проучване върху ефективността и безопасността на тоцилизумаб при пациенти с рефрактерен ТАК. Въпреки че първичната крайна цел (време до релапс на ТАК) не е постигната, резултатите демонстрират предимство на тоцилизумаб спрямо плацебо при добро ниво на безопасност [17]. Описаният случай демонстрира дългосрочния ефект на лечението c IL-6 рецепторно антитяло при пациент с ТАK.

\section{ПРЕДСТАВЯНЕ НА СЛУЧАЯ}

Пациентката е 21-годишна жена от бялата раса, на възраст 15 години, която през месец август 2011 г. е диагностицирана с ТАК според критериите за поставяне на диагноза на Американската колегия по ревматология - American College of Rheumatology (ACR) [4]. Първоначалните симптоми са умора, редукция на теглото (20 кг за 8 мес.), загуба на апетит, болка в шийната област, в лявата ръка и епизодична болка в корема.

От фризикалния статус се установиха плътна продълговата формация с размер 1/4 см по протежение на дясната каротидна артерия, отслабени пулсации на лявата брахиална артерия, липсващи пулсации на лявата радиална артерия, разлики в измереното артериално кръвно налягане (дясна ръка - 115/70 mm Hg, лява ръка 90/50 mm Hg). Върху каротидните артерии и абдоминалната аорта се аускултира систолен шум.

От лабораторните изследвания се регистрираха следните отклонения - нормоцитна нормо-
TNF-inhibitors can be considered as a second-line treatment after failure of conventional DMARD therapy [9]. Biologic treatment with TNF-blockers has demonstrated clinical benefits and a steroid-sparing effect in patients with TAK refractory to conventional immunosuppressive therapy, but there are no randomised controlled studies [6, 13, 14, 20]. Evidence exists regarding the effect of IL-6 receptor (IL-6R) antibody in patients with TAK, including those refractory to TNF-blockers $[2,8,16,19,22$, 23]. Until now, there is only one randomised, double-blind, placebo-controlled trial about the efficacy and safety of tocilizumab in patients with refractory TAK. Although the primary endpoint (time to relapse of TAK) was not met, the results suggest favour for tocilizumab over placebo without new safety concerns [17]. The following case report shows the long-term effect of treatment with IL-6 receptor antibody in a patient with TAK.

\section{Case Presentation}

The patient is a 21-year-old Caucasian woman, who was diagnosed as having TAK in August 2011 at the age of 15 years, according to the American College of Rheumatology criteria for the classification of TAK [4]. The presenting symptoms were fatigue, loss of weight (20 kg for 8 months), loss of appetite, pain in the neck region, and the left arm, intermittent abdominal pain.

From the physical examination the following findings were present - dense, elongated mass with size $1 / 4 \mathrm{~cm}$ along the right carotid artery, decreased left brachial artery pulse, absent left radial artery pulse, discrepancies in blood pressure (right arm - 115/70 $\mathrm{mm} \mathrm{Hg}$, left arm $-90 / 50 \mathrm{mmHg}$ ), systolic arterial bruit over the carotid arteries and the abdominal aorta.

The following laboratory abnormalities were registered - normocytic normochromic anaemia with a hemoglobin level of $105 \mathrm{~g} / \mathrm{l}$ and elevated acute-phase reactants - Erythrocyte Sedimentation Rate (ESR) $115 \mathrm{~mm} / \mathrm{h}$, C-reactive Protein (CRP) $96 \mathrm{mg} / \mathrm{L}$.

Echocardiography showed dilated ascending aorta with a diameter of $4.1 \mathrm{~cm}$. Arteriographic abnormalities were also present - aneurismal dilation from the beginning of the ascending aorta to the lev- 
хромна анемия с хемоглобин 105 г/л, и повишени острофразови реактанти (ОФР) - скорост на утаяване на еритроцитите (СУЕ) 115 мм/ч, С-реактивен протеин (CRP) 96 мм/л.

От извършената ехокардиография се установи дилатация на асцендентната аорта с диаметър 4.1 см. С артериография се констатира аневризмена дилатация от началото на асцендентната аорта до нивото на лиеналната артерия и стеноза на лявата подключична артерия.

Инициира се терапия с преднизолон 60 мг/дн. и антиагрегант. Проведоха се 3 пулса с циклофосфамид (респективно 400, 250 и 200 мг), след което се премина на поддържаща терапия с циклофосфамид 50 мг/дн., перорално. При последващ опит за намаляване на дозата на преднизолона до 25 мг/дн. настъпи възобновяване на симптомите и повишаване на ОФР. От 2011 г. пациентката периодично е на лечение с пулсове метилпреднизолон (1000 мг/дн. в продължение на 3 последователни дни) и циклофосфамид, достигайки до кумулативна доза на циклофоссрамида 8,0 г. Поддържащата терапия е перорален ГКС в доза поне 25 мг/ дн., но нито един от приложените медикаменти не доведе до пълен контрол над болестната активност. Последната инфузия на циклофосфамид беше през ноември 2014 г. Един месец след нея пациентката получи значителна хематурия и беше приета в Клиниката по урология за извършване на цистоскопия. От хистологичното изследване се установи хроничен хеморагичен цистит, който беше интерпретиран като страничен ефект от лечението с циклофосфамид. Оттогава се преустанови терапията с циклофосфамид. От месец декември 2014 г. пациентката провежда лечение първоначално с азатиоприн (100 мг/дневно), след което с метотрексат (10 мг/седмично), в комбинация с перорален ГКС в доза поне 25 мг/дн. Поради изява на странични реакции от имуносупресивната терапия (стомашно-чревна непоносимост) тя се преустанови.

През месец юни 2015 г. пациентката се оплака от болка във врата, болка при натоварване и слабост на лява ръка и редукция на теглото през последния месец със 7 кг на фона на терапия с 25 мг/дн. преднизолон. От физикалното изследване се установиха някои странични ефекти от продължителното ГКС лечение (facies lunata, стрии по ґрдите, корема и бедрата), както и разлика в артериалното кръвно налягане (дясна ръка - 110/70 $\mathrm{mm} \mathrm{Hg}$, лява ръка - 80/40 mm Hg), отслабени пулсации на брахиалната артерия и липсващи пулсации на лявата радиална артерия, систолен шум el of the splenic artery and stenosis of the left subclavian artery.

Treatment with $60 \mathrm{mg} /$ day prednisolone was initiated, together with an antiplatelet drug. Three pulses with cyclophosphamide $(400,250$, and 200 $\mathrm{mg}$, respectively) were administered, followed by maintenance therapy of oral cyclophosphamide $50 \mathrm{mg} /$ day. A subsequent reduction in the prednisolone dosage to $25 \mathrm{mg} /$ day was followed by a recurrence of the symptoms, together with an elevation of the acute-phase reactants. Since 2011, the patient had been treated intermittently with pulse therapy with methylprednisolone $(1,000$ $\mathrm{mg} /$ day for 3 consecutive days) and cyclophosphamide, reaching a cumulative dose of $8,0 \mathrm{~g}$ of cyclophosphamide. The maintenance therapy was oral corticosteroids at a dosage of at least $25 \mathrm{mg} /$ day, but none of these medications fully controlled the disease activity. The last cyclophosphamide infusion was in November 2014. A month after it, the patient presented with profuse haematuria and was admitted to Urology Clinic for cystoscopy. The histology revealed chronic haemorrhagic cystitis, which was interpreted as an adverse effect of cyclophosphamide. Therapy with cyclophosphamide was ceased. Since December 2014, the patient had been treated first with oral azathioprine (100 $\mathrm{mg} / \mathrm{day}$ ), followed by methotrexate (10 mg/week), together with oral corticosteroids at a dosage of at least $25 \mathrm{mg} /$ day, but due to side effects (gastrointestinal intolerance), the immunosuppressants were ceased.

In June 2015, the patient complained of cervical pain, pain on exertion and weakness in the left arm, and a $7 \mathrm{~kg}$ weight loss in 1 month. At that time, the prednisolone dosage was $25 \mathrm{mg} /$ day. The physical examination demonstrated some side effects from the long-term treatment with GCs (moon face, striae over the breasts, abdomen, and thighs), as well as discrepancy in the blood pressure (right arm 110/70 mm Hg, left arm - 80/40 mm Hg), decreased left brachial artery pulse and absent left radial artery pulse, bilateral systolic bruit over the carotid arteries, louder over the left carotid artery, systolic bruit over the left subclavian artery and the abdominal aorta. ESR was $86 \mathrm{~mm} / \mathrm{h}$, serum CRP level was 105 
двустранно върху каротидните артерии, по-силен върху лявата, систолен шум върху лявата подключична артерия и върху абдоминалната аорта. Регистрира се CУE 86 мм/ч, серумно ниво на CRP 105 мг/л. От извършената ехокардиография се установиха прогресиране на аневризменото разширение на асцендентната аорта и високостепенна обструкция на лявата подключична артерия. На КАТ на гръден кош и на корем се визуализира циркулярна неправилна дилатация на стената на асцендентната и на десцендентната аорта, която продължава до лиеналната артерия.

Поради честите релапси на заболяването, прогресията на съдовото увреждане, описаните странични ефекти от имуносупресорите и от ГКС се обмисли добавяне към терапията на антитяло срещу рецептора за IL-6. Лечението с тоцилизумаб беше одобрено от Етичната комисия към УМБАЛ „Каспела“ и пациентката подписа информирано съгласие. При включване на тоцилизумаб към терапията (юни 2015 г.) дозата ГКС не се повиши.

Две седмици след иницииране на терапия с подкожен тоцилизумаб в доза 162 мг/седмично пациентката съобщи за намаляване на болката във врата и лявата ръка и за повишен апетит. След едномесечно лечение СУЕ спадна до 32 мм/ч и нивото на CRP до 8 мг/л. Doppler ехокардиографията установи повишен кръвоток в лявата подключична артерия. Преди започване на лечението пулсациите на лявата брахиална артерия бяха силно отслабени. На седмица 24 пулсациите на лявата брахиална артерия се палпираха по-лесно. Намаляването на дозата на преднизолона започна на седмица 4 след иницииране на терапията с тоцилизумаб и беше успешно, без релапс на болестната активност. На седмица 16 (октомври 2015 г.) преднизолонът се изведе и пациентката остана само на терапия с тоцилизумаб. Клиничните симптоми и лабораторните показатели на пациентката бяха мониторирани на всеки 3 мес. за период от 2 години, без да настъпи релапс на болестната активност. По време на проследяването не се установиха признаци на биологична активност на заболяването - пациентката не съобщи за възвръщане на симптомите и ОФР бяха в референтни стойности. Не бяха отчетени странични ефекти от терапията с тоцилизумаб.

\section{ОБсъждане}

Лечението на ТАК цели контрол над болестната активност и предотвратяване на съдовата увреда при свеждане до минимум на дългосроч- $\mathrm{mg} / \mathrm{L}$. Echocardiography showed the progression of the aneurysmal dilation of the ascending aorta and high-grade obstruction of the left subclavian artery. Chest and abdomen CT demonstrated circular irregular dilation of the wall of the ascending aorta and the descending aorta, which continued to the splenic artery.

Because of the frequent relapses of the disease, the progression of the vascular damage, the experienced side effects from the immunosuppressants, and the GCs, an anti-IL6-receptor antibody was considered as a therapeutic option. The use of tocilizumab for this patient was approved by the ethics committee of the University Hospital' Kaspela', and written informed consent was obtained from the patient. At the time tocilizumab treatment was initiated (June 2015), the corticosteroid dose was not increased.

Two weeks after the initiation of subcutaneous tocilizumab $162 \mathrm{mg} /$ week, the patient reported decreased pain in the cervical region and the left arm and an increased appetite. After one month of treatment, ESR dropped to $32 \mathrm{~mm} / \mathrm{h}$ and CRP level to $8 \mathrm{mg} / \mathrm{L}$. Doppler echocardiography showed an increase in blood flow in the left subclavian artery. Before treatment initiation, the patient's left brachial artery pulse was very weak. At week 24, the left brachial artery pulse became more palpable. Tapering of prednisolone started at week 4 after initiation of tocilizumab and was accomplished without a disease flare. At week 16 (October 2015), prednisolone was ceased, and the patient remained on tocilizumab therapy only. The patient's clinical symptoms and laboratory parameters were monitored every three months for a period of 2 years without any relapse of the disease. During the follow-up, there was no evidence of biologic activity of the disease - the patient did not report any recurrence of the symptoms, and the acute-phase reactants remained within normal limits. Tocilizumab did not lead to any side effects.

\section{Discussion}

Treatment of TAK should control disease activity and prevent vascular damage, with minimal long-term side effects. There is evidence that ap- 
ните странични ефекти на терапията. Има данни, че приблизително половината пациенти отговарят на лечението с ГКС [21]. До момента не е установен значим клиничен ефект на имуносупресорите при ТАК. Поради липсата на резултат от конвенционалното лечение при всички пациенти и честите дългосрочни странични ефекти от употребата на ГКС са необходими нови терапевтични опции при болните с ТАК. В биологичната ера се натрупват все повече доказателства за ефекта на антитялото срещу рецептора на IL-6 при лечението на LVV и тоцилизумаб е включен в последните препоръки на EULAR от 2020 г. за лечение на пациентите c LVV [1, 9].

В нашия случай тоцилизумаб редуцира клиничните прояви на заболяването и лабораторните възпалителни маркери при пациентка с рефрактерен ТАК, което даде възможност за намаляване и впоследствие за спиране на ГКС, без изява на релапс на болестната активност за периода на проследяване от 2 години. Всичко това потвърждава ключовата роля на IL-6 в патогенезата на този васкулит. С цел предотвратяване на необратимо увреждане на органите, вероятно ще е по-полезно биологичното лечение да се инициира рано в хода на заболяването.

\section{ЗАКЛЮЧЕНИЕ}

IL-6 рецепторното антитяло тоцилизумаб може да бъде терапевтична опция при пациентите с рефрактерен ТАК. Необходими са още проучвания за потвърждаване на ползата от дългосрочното лечение c IL-6-рецепторно антитяло при пациентите с ТАК.

\section{Библиография / References}

1. Димов Д. Актуални възможности и перспективи на биологичните средства в лечението на системните васкулити. II. Биологични средства при артериита на Takayasu. Ревматология 2014; 22(3-4):3-12.

2. Abisror N, Mekinian A, Lavigne $\mathrm{C}$, et al. Tocilizumab in refractory Takayasu arteritis: a case series and updated literature review. Autoimmun Rev 2013;12:1143-9.

3. Alibaz-Oner F, Yentür SP, Saruhan-Direskeneli G, Direskeneli H. Serum cytokine profiles in Takayasu's arteritis: search for biomarkers. Clin Exp Rheumatol 2015;33:S-32-5.

4. Arend WP, Michel BA, Bloch DA, et al. The American College of Rheumatology 1990 criteria for the classification of Takayasu arteritis. Arthritis Rheum 1990;33:1129-34.

5. Brunner J, Feldman BM, Tyrrell PN, et al. Takayasu arteritis in children and adolescents. Rheumatology 2010;49:1806-14. proximately half of the patients treated with steroids respond to treatment [21]. Immunosuppressive agents have not shown major clinical benefits in TAK. Due to the lack of universal success with conventional treatment for TAK and the frequent side effects of long-term GCs treatment, new therapeutic options are needed. In the biologic era, the evidence is accumulating regarding the effect of anti-IL-6 receptor antibody for the treatment of LVV and tocilizumab is included in the latest 2020 EULAR recommendations for the management of patients with LVV $[1,9]$.

In our case, tocilizumab led to a reduction of the clinical manifestations and laboratory markers of inflammation in our patient with refractory TAK, which allowed tapering and the consequent cessation of the corticosteroid without a disease flare for a follow-up period of 2 years. This confirms the major role of IL-6 in the pathogenesis of this vasculitis. In order to prevent irreversible organ damage, it might be more beneficial to introduce this biologic treatment early in the course of the disease.

\section{Conclusion}

IL-6 receptor antibody tocilizumab might be a therapeutic option for patients with refractory TAK. Further research is required to confirm the benefits of long-term treatment with IL-6 receptor antibody in patients with TAK.

6. Clifford A, Hoffman GS. Recent advances in the medical management of takayasu arteritis: an update on use of biologic therapies. Curr Opin Rheumatol 2014;26:7-15.

7. Dejaco C, Ramiro S, Duftner C, et al. EULAR recommendations for the use of imaging in large vessel vasculitis in clinical practice. Ann Rheum Dis. 2018;77:636-643.

8. Goel R, Danda D, Kumar S, Joseph G. Rapid control of disease activity by tocilizumab in 10" difficult-to-treat' cases of takayasu arteritis. Int J Rheum Dis 2013;16:754-61.

9. Hellmich B, Agueda A, Monti S, et al. 2018 Update of the EULAR recommendations for the management of large vessel vasculitis. Ann Rheum Dis. 2020 Jan;79(1):19-30.

10. JCS Joint Working Group. Guideline for management of vasculitis syndrome (JCS 2008). Japanese Circulation Society. Circ J 2011;75:474-503.

11. Johnston SL, Lock RJ, Gompels MM. Takayasu arteritis: a review. J Clin Pathol 2002;55:481-6. 
12. Kong $X$, Sun $Y, M a L$, et al. The critical role of $I L-6$ in the pathogenesis of takayasu arteritis. Clin Exp Rheumatol 2016;34(Suppl 97):S21-7.

13. Koster MJ, Matteson EL, Warrington KJ. Recent advances in the clinical management of giant cell arteritis and takayasu arteritis. Curr Opin Rheumatol 2016;28:211-7.

14. Mekinian A, Comarmond C, Resche-Rigon M, et al. Efficacy of biological-targeted treatments in takayasu arteritis: multicenter, retrospective study of 49 patients. Circulation 2015;132:1693-700.

15. Meller J, Strutz F, Siefker U, et al. Early diagnosis and follow-up of aortitis with [(18)F]FDG PET and MRI. Eur J Nucl Med Mol Imaging 2003;30:730-6.

16. Nakaoka $Y$, Higuchi $\mathrm{K}$, Arita $\mathrm{Y}$, et al. Tocilizumab for the treatment of patients with refractory takayasu arteritis. Int Heart J 2013;54:405-11.

17. Nakaoka Y, Isobe M, Takei S, et al. Efficacy and safety of tocilizumab in patients with refractory Takayasu arteritis: results from a randomised, double-blind, placebo-controlled, phase 3 trial in Japan (the TAKT study). Ann Rheum Dis. 2017 Nov 30. pii: annrheumdis-2017-211878. doi: 10.1136/ annrheumdis-2017-211878.

Постъпил за печат: 13.01.2020 г.

$\triangle$ Адрес за кореспонденция:

Д-р Таня Любомирова Сапунджиева

e-mail: taniasapundjieva@abv.bg
18. Park MC, Lee SW, Park YB, Lee SK. Serum cytokine profiles and their correlations with disease activity in takayasu's arteritis. Rheumatology 2006;45:545-8.

19. Salvarani C, Magnani L, Catanoso MG, et al. Rescue treatment with tocilizumab for takayasu arteritis resistant to TNF-a blockers. Clin Exp Rheumatol 2012;30(Suppl 70):S90-3.

20. Schmidt J, Kermani TA, Bacani AK, et al. Tumor necrosis factor inhibitors in patients with Takayasu arteritis: experience from a referral center with long-term follow-up. Arthritis Care Res 2012;64:1079-83.

21. Shelhamer JH, Volkman DJ, Parrillo JE, et al. Takayasu's arteritis and its therapy. Ann Intern Med. 1985;103(1):121-6.

22. Tombetti E, Franchini S, Papa M, et al. Treatment of refractory takayasu arteritis with tocilizumab: 7 Italian patients from a single referral center. J Rheumatol 2013;40:2047-51.

23. Unizony S, Arias-Urdaneta L, Miloslavsky E, et al. tocilizumab for the treatment of large-vessel vasculitis (giant cell arteritis, Takayasu arteritis) and polymyalgia rheumatica. Arthritis Care Res 2012;64:1720-9.

24. Watanabe Y, Miyata T, Tanemoto K. Current clinical features of new patients with takayasu arteritis observed from cross-country research in Japan: age and sex specificity. Circulation 2015;132:1701-9.

Submitted: 13.01.2020

Correspondence address:

Tania Ljubomirova Sapundjieva, MD

e-mail: taniasapundjieva@abv.bg 